\title{
FASLG wt Allele
}

National Cancer Institute

\section{Source}

National Cancer Institute. FASLG wt Allele. NCI Thesaurus. Code C50972.

Human FASLG wild-type allele is located within $1 \mathrm{q} 23$ and is approximately $8 \mathrm{~kb}$ in length.

This allele, which encodes tumor necrosis factor ligand superfamily member 6 protein, is involved in apoptotic induction. 